\title{
Online Supplement:
}

In the following tables we note the reasons why the listed works were not included in our metaanalysis. The reasons can be found in Section 2.1 of the paper and are reproduced below.

Studies were rejected for failing to meet the following criteria:

1) be peer reviewed and widely accessible;

2) describe the radioactive sample in detail, including weight and elemental and isotopic compositions;

3) describe the experimental apparatus in sufficient detail to assess potential analytical sources of error;

4) yield results with an appropriate signal/noise ratio;

5) not be superseded by, or included in, later results from the same laboratory; and

6) include measures of uncertainty derived from presented data. 
Table for ${ }^{87} \mathrm{Rb}$

\begin{tabular}{|c|c|c|}
\hline Authors & Year & Reason \\
\hline Eklund & 1947 & 1 \\
\hline Haxel and Houtermans & 1948 & 2,3 \\
\hline Haxel et al. & 1948 & 2,3 \\
\hline Kemmerich & 1949 & 2,3 \\
\hline Curran et al. & 1951 & 1 \\
\hline Curran et al. & 1952 & 1 \\
\hline MacGregor and Wiedenbeck & 1952 & 2,3 \\
\hline Lewis & 1952 & 1 \\
\hline MacGregor and Wiedenbeck & 1953 & 1 \\
\hline MacGregor and Wiedenbeck & 1954 & 2,3 \\
\hline Flinta and Eklund & 1954 & 1 \\
\hline Libby & 1957 & 2,3 \\
\hline Flynn and Glendenin & 1959 & 2,3 \\
\hline Glendenin & 1959 & 1 \\
\hline Rausch and Schmidt & 1960 & 1 \\
\hline McNair and Wilson & 1961 & 1 \\
\hline Beard and Kelly & 1961 & 4 \\
\hline Egelkraut and Leutz & 1961 & 2,3 \\
\hline Leutz et al. & 1962 & 2,3 \\
\hline Kovách & 1964 & 1 \\
\hline Brinkmann et al. & 1965 & $2,3,4$ \\
\hline Thode et al. & 1965 & 1 \\
\hline McMullen et al. & 1966 & 2,3 \\
\hline Neumann and Huster & 1972 & 1 \\
\hline Davis et al. & 1977 & 5 \\
\hline Davis & 1978 & 1 \\
\hline Rotenberg et al. & 2004 & 1 \\
\hline Rotenberg et al. & 2005 & 1 \\
\hline Rotenberg et al. & 2009 & 1 \\
\hline
\end{tabular}


Table for ${ }^{147} \mathrm{Sm}$

\begin{tabular}{|c|c|c|}
\hline Authors & Year & Reason \\
\hline Hosemann & 1936 & 2 \\
\hline Picciotto & 1949 & 1 \\
\hline Beard and Wiedenbeck & 1954 & 2,3 \\
\hline Beard and Kelly & 1958 & 2,3 \\
\hline Karras and Nurmia & 1960 & 2,3 \\
\hline Karras & 1960 & 1 \\
\hline Macfarlane and Kohman & 1961 & 2 \\
\hline Valli et al. & 1965 & 1 \\
\hline Al-Bataina and Jänecke & 1987 & 1 \\
\hline Martins et al. & 1992 & 2 \\
\hline Kinoshita et al. & 2003 & 2,3 \\
\hline
\end{tabular}

Table for ${ }^{176} \mathrm{Lu}$

\begin{tabular}{|c|c|c|}
\hline Authors & Year & Reason \\
\hline McNair & 1961 & 1 \\
\hline Donhöffer & 1964 & 2,3 \\
\hline Brinkman et al. & 1965 & 4 \\
\hline Sakamoto & 1967 & 2,3 \\
\hline Sato et al. & 1983 & 1 \\
\hline Nir-El and Lavi & 1998 & 5 \\
\hline Luo and Kong & 2006 & 6 \\
\hline Hult et al. & 2013 & 2 \\
\hline
\end{tabular}

Table for ${ }^{230 T h}$

\begin{tabular}{|c|c|c|}
\hline Authors & Year & Reason \\
\hline Curie and Cotelle & 1930 & 1 \\
\hline Soddy & 1931 & 1 \\
\hline
\end{tabular}

Table for ${ }^{232} \mathrm{Th}$

\begin{tabular}{|c|c|c|}
\hline Authors & Year & Reason \\
\hline Kovarik and Adams Jr. & 1938 & 6 \\
\hline Picciotto and Wilgain & 1956 & 2,3 \\
\hline LeRoux and Glendenin & 1963 & 1 \\
\hline
\end{tabular}


Table for ${ }^{235} U$

\begin{tabular}{|c|c|c|}
\hline Authors & Year & Reason \\
\hline Nier & 1939 & 3,4 \\
\hline Kienberger & 1949 & 4 \\
\hline Knight & 1950 & 1 \\
\hline Sayag & 1951 & 1 \\
\hline Clark et al. & 1957 & 1 \\
\hline Würger et al. & 1957 & 1 \\
\hline Deruytter et al. & 1965 & 5 \\
\hline Bueno and Santos & 1993 & 3,4 \\
\hline
\end{tabular}

Table for ${ }^{238} \mathrm{U}$

\begin{tabular}{|c|c|c|}
\hline Authors & Year & Reason \\
\hline Schiedt & 1935 & 1 \\
\hline Curtis et al. & 1941 & 1 \\
\hline Kovarik and Adams & 1941 & 5 \\
\hline Kienberger & 1949 & 2 \\
\hline Kovarik and Adams & 1955 & 2 \\
\hline Lechman and Schmitt & 1957 & 2 \\
\hline Steyn and Strelow & 1960 & 2 \\
\hline
\end{tabular}

\section{References}

Al-Bataina, B., Jänecke, J. (1987) Half-lives of long-lived alpha emitters. Radiochim. Acta. 42, 159-164.

Beard G.B. and Kelly W.H. (1961) "Self-scintillation" study of the beta decay of Rb87. Nuclear Physics 28, 570-577.

Beard, G. B. and Kelly, W. H. (1958) The use of a samarium loaded liquid scintillator for the determination of the half-life of Sm147. 8, 207-209.

Beard, G. B. and Wiedenbeck, M. L. (1954) Natural Radioactivity of Sm147. Phys. Rev. 95, 1245-1246.

Brinkman, G. A., Aten, A. H.W. and Veenboer, J. Th. (1965) Natural radioactivity of K-40, Rb-87 and Lu176. Physica. 31, 1305-1319.

Brinkmann G.A., Aten Jr. A.H.W., and Veenboer J. Th. (1965) Natural radioactivity of K-40, Rb-87 and Lu176. Physica 31, 1305-1319.

Bueno C. C. and Santos M. D. S. (1993) Measurement of the absolute activity of $235 \mathrm{U}$ by the generalised coincidence method. Appl. Rad. Iso. 44, 567. 
Clark, F.L., Spencer-Palmer, H.J., Woodward, R.N., (1957) The determination of the half-lives and aparticle energies of some radioactive isotopes. Part I. The determination of the half-lives of uranium-235 and uranium-238. J. S. Afr. Chem. Inst. 2, 62.

Curie, P. and Cotelle, S. (1930) Sur la vie moyenne de l'ionium. Compt. Rendus.

Curran S.C., Dixon D., and Wilson H.W. (1951) The natural radioactivity of rubidium. Phys. Rev. 84, 151152.

Curran S.C., Dixon D., and Wilson H.W. (1952) The natural radioactivity of rubidium. Phil. Mag. 43, 82-92.

Curtis L. F., Stockman L. L. and Brown B. W. (1941) Intercomparison of mass spectrometer and alphaparticle methods for isotopic analysis. US National Bureau of Standards Report No. A-80 US GPO.

Davis D.W. (1978) Determination of the 87Rb decayconstant: An Rb/Sr and Pb/Pb study of the Labrador Archean complex. Ph.D. Thesis, Univ. Alberta.

Davis D. W., Gray J., Cumming G. L., (1977) Determination of the 87Rb decay constant. Geo. Cosmo. Acta. 41, 1745-1749.

Deruytter A.J., Schroder I.G., Moore J.A., (1965) Measurement of the half-life of $235 \mathrm{U}$ for alphaemission. Nucl. Sci. Eng. 21, 325.

Donhöffer, D. (1964) Bestimmung der Halbwertszeiten der in der Natur vorkommenden radioaktiven Nuklide Sm147 und Lu176 mittels flüssiger Szintillatoren. Nucl. Phys. 50, 489-496.

Egelkraut K. and Leutz H. (1961) $\beta$-Spektrum und Halbwertszeit des Rb87. Z. Phys. 161, 13-19.

Eklund S. (1947) The half-life period of 87Rb. Arkiv Mat., Astronom. Fysik (A)[Full title: Arkiv för Matematik, Astronomi och Fysik] 33a, 60.

Flinta J. and Eklund S. (1954) On the radioactivity of Rb87. Ark. Fys. [full title: Arkiv för Fysik] 7, 401.

Flynn K.F. and Glendenin L.E.(1959) Half-life and beta spectrum of Rb87. Phys. Rev. 116, 744-748.

Glendenin L.E. (1959) Present status of the decay constants. Ann. New York Acad. Sci. 91, 166-179.

Haxel O. and Houtermans F.G. (1948) Gleichzeitige Emission von zwei Elektronen beim radioaktiven Zerfall des Rubidium 87. Z. Phys. 124, 705-713

Haxel O., Houtermans F.G., and Kemmerich M. (1948) On the half-life of Rb87. Phys. Rev. 74, 1886-1887.

Hosemann, R. (1936) Die Radioaktivität des Samariums. Z. Phy. 99, 405-427.

Hult M., Vidmar T., Rosengard U., Marissens G., Lutter G., Sahin N. (2013) Half-life measurements of lutetium-176 using underground HPGe-detectors. Appl. Rad. Iso. In Press

Karras, M. (1960) On the natural radioactivity of samarium. Ann. Acad. Sci. Fennicae. 65.

Karras, M. and Nurmia, M. (1960) Natural radioactivity of samarium and neodymium. Nature. 185.

Kemmerich M. (1949) Die Halbwertszeit des Rubidiums. Z. Phys. 126, 399-409. 
Kienberger, C. A. (1949) The uranium-234 content of natural uranium and the specific alpha-activities of the isotopes. Phys. Rev. 76, 1561.

Kinoshita, N., Yokoyama, A. and Nakanashi, T. (2003) Half-life of samarium-147. J. Nucl. Radiochem. Sci. 4, 5-7.

Knight, G. B. (1950) Specific Alpha Activity of 235U. Oak Ridge Nat. Lab. Report. K-663.

Kovách A. (1964) A re-determination of the half-life of rubidium-87. Acta Phys. (Hung.) 17, 341-351.

Kovarik, A. F. and Adams Jr., N. I. (1941) The rate of emissions of $\alpha$-particles from uranium and the relative activity of actinouranium. J. Appl. Phys. 12, 296.

Kovarik, A. F. and Adams Jr., N. I. (1938) The disintegration constant of thorium and the branching ratio of thorium C. Phys. Rev. 54, 413-421.

Kovarik, A. F. and Adams Jr., N. I. (1955) Re-determination of the disintegration constant of 238U. Phys. Rev. 98, 46.

Lechman, R. B. and Schmitt, H. W. (1957) The cross-section for 238 U fission by fission neutrons. J. Nucl. Energy. 4, 38.

LeRoux, L. J. and Glendenin, L. E. (1963) Half-life of 232Th. Proc. National Meeting on Nuc. Energy. 83.

Leutz H., Wenninger H., and Ziegler K. (1962) Die Halbwertszeit des Rb87. Z. Phys. 169, 409-416.

Lewis G.M. (1952) The natural radioactivity of rubidium. Phil. Mag. 43, 1070-1074.

Libby W.F. (1957) Simple absolute measurement technique for beta radioactivity. Anal. Chem. 29, 15661570.

Luo J., Kong X., (2006) Half-life of 176Lu. Appl. Rad. Iso. 64, 588-590

Macfarlane, R. D. and Kohman, T. P. (1961) Natural Alpha Radioactivity in Medium-Heavy Elements. Phys. Rev. 121, 1758-1769

MacGregor M.H. and Wiedenbeck M.L. (1952) The decay of rubidium 87. Phys. Rev. 86, 420-421.

MacGregor M.H. and Wiedenbeck M.L. (1953) The decay of rubidium 87. In Proceedings of the Conference on Nuclear Processes in Geologic Settings1 (abstract). pp. 1-3.

MacGregor M.H. and Wiedenbeck M.L. (1954) The third forbidden beta spectrum of rubidium-87. Phys. Rev. 94, 138-140.

Martins, J. B., Terranova, M. L. and Moreira Correa, M. (1992) Half-life for alpha-decay of 147Sm. II Nuovo Cimento. 105, 1621-1626.

McMullen C.C., Fritze K., and Tomlinson R.H. (1966) The half-life of rubidium-87. Can. J. Phys. 44, 30333038.

McNair A. and Wilson H.W. (1961) The half-life of rubidium-87. Phil. Mag. 6, 563-572 .

McNair, A. (1961) The half-life of long-lived lutetium-176. Philos. Mag. 6, 851-856. 
Neumann W. and Huster E. (1972) Neubestimmung der Halbwertszeit des 87Rubidiums durch Vergleich von Messungen an den getrennten Isotopen 87Rb und 87Rb. Z. Naturforsch. 27a, 862.

Nier A.O., (1939) The isotopic constitution of radiogenic lead and the measurement of geological time II. Phys. Rev. 55, 150.

Nir-El Y. and Lavi N. (1998) Measurement of the Half-life of 176Lu. Appl. Rad. Iso. 49, 1653-1655.

Picciotto E. (1949) Study of the Rdioactivity of Samarium by the Photographic Method. Compt. Rend. 229.

Picciotto E. and Wilgain S. (1956) Confirmation de la periode du thorium-232. II Nuovo Cimento. 4, 15251528.

Rausch W. and Schmidt W. (1960) Neubestimmung der Halbwertszeit des 87Rb. Physikalische Verhandlungen $11,66$.

Rotenberg E., Davis D.W., and Amelin Y. (2004) Determination of the 87Rb decay-constant by 87Sr accumulation. 32nd Int. Geol. Congr., Abs. Vol., pt. 1, abs. 172-5, p. 811.

Rotenberg E., Davis D.W., and Amelin Y. (2005) Determination of the 87Rb decay-constant by 87Sr accumulation. 15th Annual V.M. Goldschmidt Conference, Abstract. Geochim. Cosmochim. Acta 69, A326.

Rotenberg, E. (2009) The decay-constant of 87Rb and a combined U-Pb, Rb-Sr chronology of ordinary chondrites. Ph.D. Thesis, University of Toronto. (Available at https://tspace.library.utoronto.ca/bitstream/1807/19218/1/Rotenberg_Ethan_D_200911_PhD_ thesis.pdf)

Sakamoto, K. (1967) The half-lives of natural 176Lu and 180Ta. Nuc. Phys. A. 103, 134-144.

Sato J., Ohoka Y. and Hirose, T. (1983) The half-life of 176Lu. Radiochem. Radioanal. Lett. 58, 263-267.

Sayag M.G.-J. (1951) Mesure du rapport des activit! es de 235U et $234 \mathrm{U}$ dans I'uranium naturel a'I aide d'une chambre d'ionisation a grille. C. R. Acad. Sci. Paris 232, 2091.

Schiedt, R. (1935) Die Zahl der von Uran emittierten Alpha- Teilchen (the number of alpha particles emitted from uranium). Osterr. Akad. d. Wiss., Sitzungsberichte d. mathem.-naturw. Kl., Abt. Ila, 144 Bd., Heft 5 und 6, 192.

Soddy, F. (1931) LXXXIX. The relation between uranium and radium.-Part IX. The period of ionium. Phil. Mag. 12.

Steyn, J. and Strelow, F. W. E. (1960) The determination of the half- life of 238U, absolute counting of a particles in a $4 p$-liquid scintillation counter. In: Sanielevici, A. (Ed.), Metrology of Radionuclides. IAEA STI/PUB/6, Vienna, Austria, 155-161.

Thode H.G., McMullen C.C., Pleva J., Heyland G., and Tracy B. (1965) Mass Spectrometric Studies. McMaster Nuclear Reactor - Reactor Research Report. B26-B28. 
Valli, K., Aaltonen, J., Gräffe, G., Nurmia, M. and Poeyhoenen, R. (1965) Half-life of 147Sm comparison of ionization chamber and liquid scintillation results. Ann. Acad. Sci. Fenn. 177.

Würger, E., Meyer, K. P. and Huber, P. (1957) Lebensdauer und Zerfallsschema von 235U. Helv. Phys. Acta. 30, 157-182. 